\title{
Where do islands put their waste? - A material flow and carbon footprint analysis of municipal waste management in the Maltese Islands
}

\author{
Margaret Camilleri-Fenech ${ }^{\text {a, b, * }}$, Jordi Oliver-Solà ${ }^{\text {b, c }}$, Ramon Farreny b, c, \\ Xavier Gabarrell ${ }^{\text {b, }}$, \\ ${ }^{a}$ Institute for Climate Change and Sustainable Development, University of Malta, Malta \\ ${ }^{\mathrm{b}}$ Institute of Environmental Science and Technology (ICTA-Sostenipra), Universitat Autonoma de Barcelona (UAB), Campus de la UAB, 08348, Bellaterra, \\ Spain \\ ' Inèdit Innovació SL (inèdit-Sostenipra), Campus de la UAB, 08348, Bellaterra, Spain \\ d Departament Enginyeria Química, Biológica I Ambiental (XRB), Universitat Autònoma de Barcelona, Campus de la UAB, 08348, Bellaterra, Spain
}

\section{A R T I C L E I N F O}

\section{Article history:}

Received 23 June 2016

Received in revised form

11 May 2017

Accepted 7 July 2017

Available online 9 July 2017

\section{Keywords:}

$\mathrm{CO}_{2 Z W^{\circledR}}$

STAN 2.5

Waste Management Plan 2014-2020

Greenhouse gas emissions

\begin{abstract}
A B S T R A C T
Waste management on small islands does not hold any straightforward solutions. The numerous difficulties include limited space availability, restricted recycling and resale opportunities and impacts on the local environment that become magnified particularly when the island is small-sized, densely populated and tourist dependent.

The well-documented impact on the local environment includes resource loss, damage to the marine and local environment and continuous nuisances created by littering, trucks and treatment facilities. However, waste management can leave its mark beyond the local borders. The generation and treatment of waste is in fact gaining attention in its connection with greenhouse gas emissions (GHG). Although in the past GHG emissions were mainly associated with energy generation, today it is frequently acknowledged that improved waste management can also mitigate these emissions.

This research paper analysis the flows involved in the management of municipal waste (MW) from an island perspective. Focusing on the island of Malta, which consists of $316 \mathrm{~km}^{2}$ and sustains a population density of 1327 people $/ \mathrm{km}^{2}$, a Material Flow Analysis together with a carbon footprint is presented for 2012. The same analysis is then made for three prospective scenarios proposed in the Waste Management Plan for the Maltese Islands 2014-2020 using projected 2018 data.

With the use of STAN 2.5 (SubSTance Flow ANalysis), a tabled down analysis of the collection, treatment and disposal/export flows involved in the management of Municipal Waste in Malta is presented. The flows are then translated into a carbon footprint analysis using CO2ZW ${ }^{\mathbb{B} \text { (a carbon footprint tool for waste }}$ management). The objective is to emphasize the relationship between GHG remove GHG and replace with Greenhouse Gas emissions and existing waste management flows and how this relationship changes when different collection, treatment and disposal options are selected. The research's ultimate aim is therefore to underline the importance of placing climate concerns in waste management policies.

The results note that, in terms of carbon emissions, Malta stands to benefit from the introduction of a second Mechanical Biological Treatment plant since carbon emissions will experience an extensive reduction from the 2012 estimates. However, further reduction of carbon emissions should be accompanied by the increase of dry material recycling, separate organic collection and an analysis of the current collection system particularly route optimisation.
\end{abstract}

๑) 2017 Elsevier Ltd. All rights reserved.

\footnotetext{
* Corresponding author. Institute for Climate Change and Sustainable Development, University of Malta, Msida, MSD 2080, Malta.

E-mail address: margaret.camilleri-fenech@um.edu.mt (M. Camilleri-Fenech).
}

\section{Introduction}

The management of municipal waste (MW) is complex. Characterized by a multitude of generators and a varying composition it 


\begin{tabular}{|llll|}
\hline \multicolumn{2}{l|}{ Acronyms } & ISWA & International Solid Waste Association \\
& & MBT & Mechanical Biological Treatment \\
$\mathrm{CO}_{2}$ & Carbon Dioxide & MEPA & Malta Environment and Planning Authority \\
$\mathrm{EEA}$ & European Environment Agency & MFA & Material Flow Analysis \\
EfW & Energy from Waste & MRF & Material Recovery Facility \\
ETS & Emission Trading Scheme & MW & Municipal Waste \\
EU & European Union & NIMBY & Not In My Backyard \\
EUMS & European Union Member State & NIR & National Inventory Report \\
EWC & European Waste Code & RDF & Refuse Derived Fuel \\
FOD & First Order Decay & SAWTP & Sant' Antnin Waste Treatment Plant \\
GHG & Greenhouse Gas & STAN & SubSTance Flow ANalysis \\
IPCC & Intergovernmental Panel on Climate Change & UNEP & United Nations Environmental Programme \\
IPPC & Integrated Pollution and Prevention Control & & \\
& & & \\
\hline
\end{tabular}

makes the collection, disposal and treatment both multifaceted and problematic. On islands, issues with disposal and treatment are intensified by the definitive space challenges (Deschenes and Chertow, 2004) which reduce the possibility to landfill waste by a large extent (Zsigraiová et al., 2009), isolated geographies and limitations to outsource some of the waste streams (Eckelman et al., 2014) making recycling and recovery of materials problematic due to both the absence of a market for recycled materials and the distance from larger markets (Zsigraiová et al., 2009).

Indeed, for most islands, waste is considered to be a very serious problem (UNEP, 1999). Waste treatment options are land intensive and the limited availability of suitable locations, particularly in densely populated and tourist dependent islands (Agamuthu and Herat, 2014), make the demand for land rife with conflict. An additional hitch, particularly when the island is tourist dependent is visual impact which includes landfill sites that often come in full view of tourist facilities (Eckelman et al., 2014). Local authorities are therefore at a loss as to which solutions can possibly be found since waste issues seem to come in the way of "everyone and everything" magnifying the Not In My Backyard (NIMBY) syndrome (Eckelman et al., 2014; Agamuthu and Herat, 2014).

Clearly the management of waste provides an administrative, societal and market challenge. It is also a source of environmental hitches which can become magnified on islands. The welldocumented impacts include land and beach degradation, increased surface and marine pollution and raised risks for human health (UNCSD, 1999). A perhaps less documented impact, but that is gaining wider recognition, is the direct relationship that waste has with greenhouse gas emissions (GHG) (Chen and Lo, 2016). It is generally accepted that human activities have caused GHGs to accumulate in the environment (Chen and Lo, 2016). The excessive GHGs are the cause of more frequent occurrence of extreme weather which threatens the safety of human society and natural systems (Fishedick et al., 2014). Two of the sharpest spears created by global warming - flooding and draught - account for more than half of the world's deaths from natural disaster (Knauer, 2007). For the past 1 million years atmospheric $\mathrm{CO}_{2}$ has ranged between 172 and 300 part per million (ppm). Now, the crossover for concentrations that stay above $400 \mathrm{ppm}$ is nearly complete (McGee, 2015). Reducing GHG is the essential means of easing global warming and achieving sustainable development of human ecological and economic societies (Jiang et al., 2016). This is however an extremely complex problem for which there is no single solution. It is a noted fact that over time discussions about climate change mitigation have started and ended with energy consumption (Ackerman, 2000; Messenger, 2015). Although the ability of the waste management sector to reduce GHG emissions has been underestimated
(Bogner et al., 2007), it can reduce GHG significantly particularly when a life-cycle approach is adopted (EEA, 2011), that is, when GHG emissions are accounted for during the production and usage of a product, but also in its end-of-life phase during the treatment processes (Braschel and Posch, 2013).

This connection was brought to the forefront in the pivotal report published in 2010 by the United Nations Environmental Programme (UNEP) which clearly stated that the "waste sector is in a unique position to move from being a minor source to becoming a major saver of global emissions" (UNEP, 2010).

The role of waste in GHG reduction is gaining more centre stage both academically and politically. In their article, Zeng and Chen, 2016, included waste treatment as part of the carbon-industrial chain index which forms part of the overall low-carbon economy index evaluation. The garbage treatment rate, as referred to in the article, represents the absorption of carbon emissions and the prevention of secondary carbon dioxide generation after garbage treatment. The value of this index is expected to increase as treatment rate improves, therefore strengthening the low-carbon economy. Politically, the relation, became more pronounced in the Paris Agreement, where the head of the International Solid Waste Association (ISWA), David Newman, noted that "after years of fighting for a seat at the table ... ...the contribution of waste is recognized for what it is - equally as important as renewable energy, electric cars and solar panels". This assertion came particularly from donor countries who recognized that "waste was a critical issue to tackle". Specific contribution from the waste sector can go towards short lived climate pollutants like methane, black carbon and HFC gases (ISWA, 2015).

This research paper aims to portray the challenging relationship between MW and islands and accentuate the complexities involved in such systems. Furthermore it aims emphasize the importance of giving GHG emissions their due attention during the inception of waste management policies. Focusing on MW management on the island of Malta, it presents two material flow analysis (MFA) and their respective carbon footprints in order to examine the current (using 2012 as a base year) and proposed (2018) waste management flows and how the carbon emissions will change when alternative scenarios are implemented.

\section{The management of municipal waste in Malta - infrastructure and legal framework}

The Maltese Islands are made of an archipelago of six (6) islands with a total land mass of $316 \mathrm{~km}^{2}$. Three of the islands are uninhabited, whilst the majority of the population lives on the largest island, that is, Malta. The islands sustain a very high population 
density (highest in the European Union (EU) and third in the world) which in the 2011 demographic review reached an average of 1327 persons per $\mathrm{km}^{2}$ (NSO, 2011). This stress is further accentuated by one million tourists every year (NSO, 2012). Malta joined the EU on 1st June 2004.

Malta's membership in the EU exerted considerable influence on waste management. Prior to 2004, the management of waste formed part of Act XX of 2001 Environmental Protection Act. The Act itself did not give extensive detail about how and what should be done in relation to waste. However, following EU accession, waste management became extensively regulated and confronted with various targets mainly falling under the Waste Framework Directive (WFD) (Directive, 2008/98/EC transposed in Maltese legislation through Legal Notice 184 of 2011) and the Landfill Directive (Directive, 1999/31/EC transposed through Legal Notice 168 of 2002). In 2014 the Maltese Government published the Waste Management Plan 2014-2020 which positions the parameters for the different waste streams with the aim of reaching the targets set by the prescribed directives.

As noted earlier, this study is focused on MW. The Landfill Directive defines MW as "waste from households, as well as other waste which, because of its nature or composition, is similar to waste from households". Further elaboration about this definition comes from Eurostat (2011) which points out that MW is waste mainly produced by households, though similar wastes from sources such as commerce, offices and public institutions are included. In fact it notes that the amount of MW generated consists of waste collected by or on behalf of municipal authorities and disposed of through the waste management system' (Eurostat, 2012). Maltese legislation includes this observation in Legal Notice 184 of 2011 (transposes the Waste Framework Directive) which, in Article 4 specifies that, "household waste refers to waste originating from (a) domestic property; (b) a residential home; (c) premises forming part of a university or school or other educational establishments and (d) premises forming part of a hospital or nursing home". Specific calculation is based on the European Waste Catalogue which includes items listed under chapter 20 Municipal wastes together with item 150106 - mixed packaging (G. Mizzi, personal communication, November 11, 2013).

Therefore, MW includes the following types of material - paper, paperboard and paper products, plastics, glass, metals, food and garden waste and textiles, together with bulky waste (e.g. white goods, old furniture, mattresses) and garden waste, leaves, grass clippings, street sweepings, the content of litter containers, and market cleansing waste if managed as waste (Eurostat, 2012).

The management of waste in Malta exerts considerable challenges. The high population density, coupled with an intensive tourism industry leads to a higher than average MW generation rate. Although seasonal population is not taken into account in waste management policies (Saladié, 2016), a study conducted in 2006, noted that tourists in 4-star and 5-star hotels generate an average of $1.56 \mathrm{~kg} /$ person/day or $569 \mathrm{~kg} /$ person/year (Galdes, 2007). The Maltese in 2012 produced $590 \mathrm{~kg}$ per capita (the European average is $481 \mathrm{~kg}$ /capita (Eurostat, 2015, 2016). An examination of monthly flows notes an increase in July and August, however further analysis is required. These factors, coupled with a small, physically separated, land area, leave very little space for landfilling (Falzon et al., 2013), whilst making the siting of other waste facilities difficult. Physical separation also means limited recycling capacity and resale market pressing recyclers to tap foreign markets whilst escalating costs. A final point of contention is aesthetics waste and its management does not augur well for the profit generating tourism industry - together with the pervasive litter, Maghtab, the main un-engineered, now closed, dumpsite has reached enough height to be visible from almost every part of the country.

In Malta, MW, on average forms $14 \%$ of total waste generated. Although it is not the most prevalent type of waste, it is the most visible and troublesome residues of human society (Fishedick et al., 2014). This is in view of its diverse composition, multitude collection points and disparate treatment processes which require various players, processes and tools that are not present in the collection of other types of waste particularly since generators are less dispersed and in some cases the waste is more homogenous (OECD, 2013).

After 2002, major developments were undertaken in the waste sector. The old dumpsite was closed and landfilling commenced in a new engineered landfill with gas recovery known as Ta' Zwejra (Falzon et al., 2013). Upon exhaustion, another non-hazardous landfill known as Ghallis, with a 3 million $\mathrm{m}^{3}$ capacity, was constructed (MSDEC, 2013). In the case of Gozo, a waste transfer station for the receipt, sorting processing, interim storage and waste transfer was set up (MSDEC, 2013).

Furthermore, a Mechanical Biological Treatment (MBT) plant (known as Sant' Antnin Waste Treatment Plant [SAWTP]) was constructed with the intention to move up the waste management hierarchy. However, a report commissioned to examine the operations of the facility pointed towards the importance to improve efficiency since the plant has failed to generate the anticipated renewable energy (Mallia et al., 2013). One of the main causes cited was the quality of waste arriving from the 'black bag' (mixed waste) which contains a heavy load of non-organic material (MSDEC, 2013). In April 2013, the then Malta Environment and Planning Authority (MEPA), approved the planning permission of a new MBT plant. The proposed facility aims to have waste processed to extract the organic fraction and Refuse Derived Fuel (RDF) (MSDEC, 2014).

\section{GHG emissions, waste and related policy}

The EU, with its pioneer role in environmental management, has not ignored the connection between waste and GHG and adopted both an end-of-pipe and proactive approach through different instruments. The Landfill Directive obliges member states (MS) to reduce the disposal of biodegradable MW going to landfills to 35\% of the total amount (by weight) of biodegradable MW produced in 1995. This in turn has increased the popularity of MBT in Europe (IPCC, 2006), which is of significant value since waste material undergoes a series of mechanical and biological operations that, together with reducing volume, also stabilise it so as to reduce emissions from final disposal (IPCC, 2006) and therefore significantly contributes to the reduction of GHG (Gosten et al., 2011).

A more proactive approach is presented by the European Commission in COM (2014) 398 "Towards a Circular Economy: A zero waste programme for Europe". This document connects waste and GHG by intensifying technological innovation for processes, materials and products and resource management of raw materials through the promotion of waste reduction at source and recycling.

However, as noted in the report by Ballinger and Hogg (2015) prepared for Zero Waste Europe (2015), more efforts are required. In fact the report notes that "waste management policies are still not driven by climate concerns, even though the potential for GHG emission reductions through waste management is increasingly recognized and accounted for" (Ballinger and Hogg, 2015).

Malta, in the Waste Management Plan for the Maltese Islands 2014-2020, does not tackle the two areas jointly. However, focus of the plan towards increased recycling, introduce source separation of biowaste to further process it in MBT and enhance its action to reduce food waste should assist in the reduction of carbon emissions. 


\subsection{Accounting of waste related GHG emissions}

Malta signed the Paris Climate Agreement with the first wave of countries on 22nd April 2016 (United Nations, 2016). Although the Kyoto Protocol did not impose an emission reduction target on the island (MRA, n.d.), Decision 406/2009/EC, commonly known as the Effort Sharing Decision, which addresses anthropogenic emissions of GHG that are not covered by the EU's Emissions Trading Scheme (EU ETS), lays down the minimum contribution of Member States (MS) to meet the reduction commitment for the period from 2013 to 2020 for specific emissions. In this case, Malta is obliged to retain its emissions to $+5 \%$ relative to its 2005 levels until 2020 (MRA, n.d.). Therefore, since the $\mathrm{CO}_{2}$ emissions from the two local energy plants fall under the EU ETS, Decision 406/2009/EC includes all noncarbon emissions from the two plants, together with emissions from road transport and domestic navigation, waste, agriculture, industrial processes, solvent and other product use, fuel combustion in industry and in the residential, institutional and commercial sectors, as well as fugitive emissions from fuels. These emissions currently account for approximately one third of Malta's total GHG emissions (MRA, n.d.).

As an EU member state (EUMS), and in accordance with the EU's Monitoring Mechanism Articles 3(1) and 3(2) respectively, Malta has the obligation to submit an annual National GHG Emissions Inventory (National Inventory Report [NIR]) and a biennial report on Climate Change policies, measures and projections (also known as the PAMs Report) (MRA, n.d.). The former is the key instrument used for the monitoring and reporting of emissions, both in terms of sources and removals by 'sinks'. The latter, on the other hand, is to assess the projected potential progress by MS on GHG emissions limitation and reduction up to a defined year (MRA, n.d.). The National GHG Emissions Inventory Report utilizes the First Order Decay (FOD) method, which is one of the two methods provided by the Intergovernmental Panel for Climate Change (IPCC) Guidelines.

The PAM report for Malta notes that in 2011, 88.5\% of total waste related GHG emissions was methane. In view of this, the report notes that, landfill gas extraction infrastructure was installed to treat odour and noxious gas emissions from these closed sites in a regenerative thermal oxidizer. Landfill gas extraction is expected to continue until 2028 (MRA, 2013). Since landfill gas management is a condition of the IPPC permit for both facilities, both sites will be required to cap waste mass and carry out the extraction of gases for flaring or possibly combusted for energy generation (MRA, 2013).

Reports from the European Environment Agency (EEA) utilising the IPCC methodology under the NIR, note that the waste sector in the EU-28 in 2012 amounted to 3.3\% of total GHG emissions (EEA, 2012). In Malta, the waste sector reports an average of $4.6 \%$ of total GHG emissions (MRA, 2013).

A criticism often extended to IPCC inventory mechanism is that in terms of waste it caters for emissions generated within the country borders and covers impacts of landfilling, incineration, organic waste treatment and MBT. However, no reference is made to 'recycling' or 'preparation for re-use' or 'reuse'. The "waste" section emissions are limited to the recordings of direct emissions from disposal/treatment systems, whilst a number of key impacts which arise from changes in the management of waste do not appear in this section. This also means that benefits arising from improved resource and waste management are effectively recorded under other sectors (Ballinger and Hogg, 2015).

\section{Materials and methods}

\subsection{System boundary}

The system is the actual object of the MFA (Brunner and
Rechberger, 2005) and carbon footprint investigation. A system is defined by a group of elements, their interaction and the boundaries between these elements in space and time (Brunner and Rechberger, 2005). The system requires a temporal and spatial boundary (Brunner and Rechberger, 2005) together with a material boundary in order to specify which type of emissions will be accounted for (Braschel and Posch, 2013).

The system presented here is MW management in Malta. In the MFA, MW is divided according to the European Waste Code (EWC) classification discussed in Section 2. Two MFAs are presented - the first one is based on 2012 and presents the system prior to the implementation of the Waste Management Plan 2014 - 2020. The second MFA focuses on the projected 2018 system whilst analyzing three proposed scenarios, that is, (1) incineration, (2) export or (3) landfilling of the mixed waste fraction. The two MFAs use the same system boundary. Therefore, the analysis will identify how the changes implemented (or planned to be implemented) will alter the flows and how this will affect the relative carbon footprint.

The same boundary is utilized for the carbon footprint analysis but includes urban and interurban transportation, with GHG emissions being calculated in carbon dioxide equivalents (Farreny et al., 2012). Urban transportation refers to collection from urban disposal points, whilst inter-urban refers to transport of residual material from MBTs to landfill (Farreny et al., 2012) or export to foreign countries. Transport analysis was undertaken since during the collection (bulk and selective) and transport of MW for treatment or export, GHGs are emitted in the combustion of fuel. Although waste carbon analysis seldom refer to transport because they are considered to be relatively insignificant (Falzon et al., 2013), it is necessary to acknowledge their contributions (Cifrian et al., 2012) particularly in view that the development of modern waste management systems in Europe led to a remarkable increase in the distance covered (Salhofer et al., 2007). Bottlenecks in the regional treatment capacities and overcapacities in other regions, more complex collection schemes for the separate collection of recyclables and (c) longer distances covered to specialized treatment plants contributed to this increase (Salhofer et al., 2007). A huge increase in exports between 1999 and 2011 was also noted by the EU (EEA, 2012). Driven by policies like the Packaging and Packaging Waste Directive (Directive 94/62/EC), which requires MS to recycle a minimum percentage of certain waste types, MS were incentivized to trade waste particularly since recycling usually requires specific infrastructure such as sorting plants. Additionally, a critical quantity of waste is required to make recycling profitable (EEA, 2012). These factors, together with un-optimised urban collection, offered sufficient basis to include transportation in the analysis.

Both analysis undertake a lifecycle approach with the MFA providing a complete picture of the flows involved in MW management distinguished by category and following sequentially performed steps starting from household collection, followed by treatment - through sorting facilities, biological treatment, landfilling and, in some cases, export (Braschel and Posch, 2013; Sevigne et al., 2013).

\subsection{Materials}

The MFA is based on data provided by the then Malta Environment and Planning Authority (MEPA) and WasteServ Malta Ltd. In the case of 2012, input and output data about the quantities of MW reaching the different treatment facilities was provided by WasteServ Malta Ltd. Data about exports was provided by MEPA.

Since the 2018 MFA is based on a proposed system some of the data is estimated on the 2012 figures, whilst other data is based on valuations prepared by the referred entities. The figure for the total 
MW generation (263,809 tonnes) is derived from the Waste Management Plan 2014-2020 (page 208). This quantity is then divided according to the treatment capacity of different facilities. Inputs into the bulky waste, recyclables and the Gozo transfer station streams are estimations based on the 2012 figures. Figures for the inputs into the Malta North plant, were obtained from the Integrated Pollution and Prevention Control (IPPC) permit application submitted to MEPA (WasteServ Malta Ltd, 2013).

Information for the carbon footprint analysis was based on the MFAs. However, additional information was required particularly to determine the nature and efficiency of specific processes. In the 2012 CO2ZW analysis, since there is no separation of organic waste, mixed waste is processed under MBT type 1 (22.9\%) whilst the remaining is landfilled (77.1\%). The lower efficiency of this practice (Farreny et al., 2012), is noted in Mallia et al. (2013) in the Review of Operations of SAWTP which points out that both biogas production and compost (in view of the heavy metal content) are not of adequate quality (Mallia et al., 2013).

The 2018 analysis (applies to the 3 scenarios) notes improved efficiency due to the introduction of biowaste separation. A point of contention was the efficiency of source-separated recycling material. Unfortunately the operator of the MBT plant - WasteServ Malta Ltd - does not keep separate information about the rejects of each fraction, but a total figure. Therefore a sample analysis of the grey bag was obtained from MEPA which showed an efficiency of $94.6 \%$ in the case of plastic, $88.7 \%$ in the case of metals and $91.2 \%$ in the case of paper and cardboard (D.Cordina, January 13, 2015, personal communication). Since glass is not collected in the grey bag, a 1 month sample taken by WasteServ officials pointed to a $99 \%$ efficiency (R.Grech, March 17, 2015, personal communication). In the case of the 2018 MFA, it was noted that near infrared sorters were planned to be introduced (K.Ghio, July 6, 2015, personal communication) and therefore sorting efficiency would increase to 98\% (Shelnick, n.d.).

The collection of transportation data offered another challenge. All municipalities (68 in total) were contacted to obtain the route used for household waste collection however only three localities (Fontana [Gozo], Pembroke and Santa Lucia [Malta]) provided the relevant routes. The general reply was that routes are left to the waste collector. In view of this, the waste collection companies were contacted only to be told that there is no fixed route and that often routes vary according to the driver. To obtain an overview, the author ventured with the waste collection truck in the locality of St Paul's Bay to calculate the distance covered. This route, together with the provided three routes, served as a base to calculate the total kilometers covered for household waste collection.

The prevailing no-fixed route situation causes various problems with regards to collection time since sometimes routes are changed without prior advice depending on the driver with households either taking out their waste too early or too late. ${ }^{1}$ In addition to this, no form of route optimisation measures are implemented despite the fact that this is one of the most common measures taken to reduce GHG emissions emitted in relation to waste collection and transport (Braschel and Posch, 2013).

Basing it on the total $\mathrm{km}$ of roads in every locality, the routes obtained were then used as a base to calculate the total tonkm (tonnes $\mathrm{x} \mathrm{km}$ ) covered by the collection trucks on a daily basis. Furthermore, the route covered for bring-in sites collection (kerbside bin facilities) was based on the map coordinates of every bin location (Tartaglia, 2015) and the distance covered by the trucks was calculated using Google Maps. In the case of export, the

\footnotetext{
${ }^{1}$ In Malta, households are generally expected to take out their waste $1 \mathrm{~h}$ prior to collection time.
}

countries which imported Maltese waste was obtained from MEPA and the distance covered by ship and truck was calculated using Google Maps.

The $\mathrm{CO}_{2} \mathrm{ZW}^{\circledR}$ tool considers the collection truck utilized for $u r$ ban waste collection to be a 21 ton diesel run waste collection and hydraulic compression vehicle. Air emissions from fuel combustion is influenced by stop and go driving, tire, brake and road lining abrasion (Farreny et al., 2012). In the case of inter-urban transportation, the emission factor considers the vehicle to be a diesel run lorry (with a capacity greater than 16 tons). This vehicle does not require stop and go driving (Farreny et al., 2012). In view that the $\mathrm{CO}_{2} \mathrm{ZW}^{\mathbb{B}}$ tool does not account for ship emissions, it was amended and freight transport emissions were estimated at $0.116 \mathrm{~kg} / \mathrm{km}$ of $\mathrm{CO}_{2} \mathrm{eq}$ (Ecoinvent v2.2, 2015).

\subsection{Methods}

The MFA was carried out using STAN 2 Version $2.5^{\odot}$. STAN (short for subSTance flow ANalysis) (TUV, 2012). This MFA methodology was selected because it describes, investigates and evaluates the metabolism of anthropogenic systems. Additionally, it defines terms and procedures to establish material balances of a system (Brunner and Rechberger, 2005). Based on this methodology STAN 2 was utilized to demonstrate the MFAs graphically, making it possible to display the complex MW systems in a systematic manner (Cencic and Rechberger, 2008).

The carbon footprint was calculated using the $\mathrm{CO}^{2} \mathrm{ZW}^{\mathbb{R}}$ tool. Although Malta currently uses the IPCC FOD method to do this calculation, the use of the $\mathrm{CO}_{2} \mathrm{ZW}^{\mathbb{B}}$ tool allows for the identification and quantification of emissions of waste related GHG in carbon dioxide equivalents $\left(\mathrm{CO}_{2 \mathrm{eq}}\right)$ produced over the entire lifecycle (Sevigne et al., 2013). The approach allows for the clear designation of emission sources thus avoiding any possible circumvention related to origin (Braschel and Posch, 2013).

\section{Results and discussion}

The MFA presented in Fig. 1, based on 2012 figures, shows a total MW input of 248,784 tonnes, out of which 41,173 tonnes are exported. Figures for water inputs are estimates since no official statistics are kept.

Fig. 1 denotes a system that is based on landfilling. The thick orange line denotes a total of 175,003 tonnes of MW that are directly landfilled. The MBT received 52,069 tonnes (blue line), out of which 35,153 tonnes (67.5\%) are also landfilled directly. The remaining 19,341 tonnes are sent to the Wet MTP (17,420 tonnes) and to the Material Recovery Facility (MRF) (1,921 tonnes). A total of 21,712 tonnes of dry recyclables are separately collected (red line), whilst 2425 tonnes (consisting mainly of dry recyclables) are redirected from the landfill back to the MBT.

Fig. 1 denotes a directed graph (left to right) with a waste disposal system that shows a predominantly linear waste treatment system. In fact, it is only 20,979 tonnes $(8.43 \%)$ of waste that are recovered recyclables. As noted in the Review of Operations, 667 tonnes of biogas are recovered, this is generally of poor quality (Mallia et al., 2013).

Since in 2012 there was no separation of organic waste a loss of resources is prevalent. A suggested use of the MFA is for the assessment of the circularity of the current system particularly in view of Malta's preparation for the Circular Economy package.

The MFA also denotes the gas collected from Ghallis and Zwejra, the two engineered landfills together with the closed Maghtab landfill. Gas collected from Ghallis and Zwejra amounts to 4,279 tonnes and 4,418 tonnes respectively. Here, the gas has a higher calorific value in view that waste disposed in the old land rise has a 


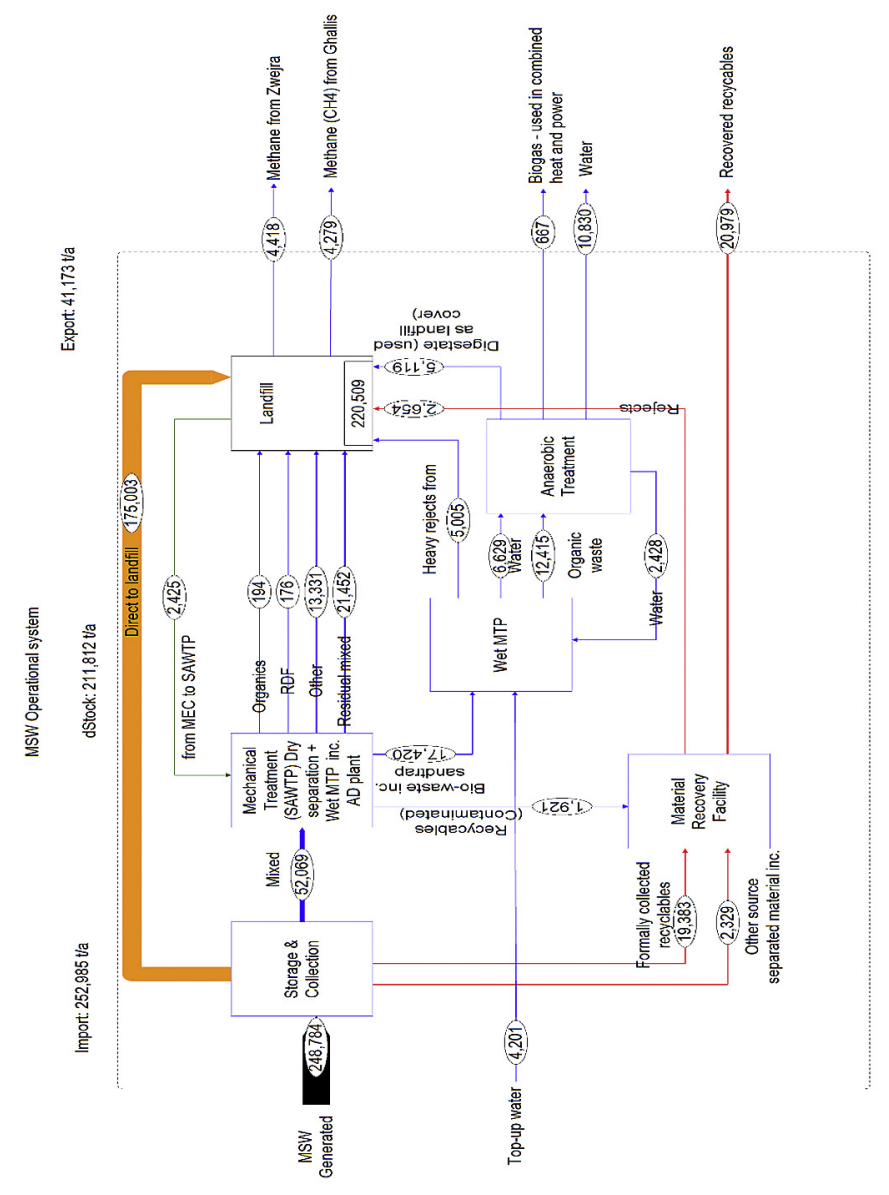

Fig. 1. MFA of the management of municipal waste in Malta in 2012 (in tonnes).

Source: WasteServMalta Ltd and Waste Management Unit, MEPA.

high content of construction and demolition waste whilst in the case of the engineered landfills waste consist mainly of mixed MW. In view of this, a different treatment via a Regenerative Thermal Oxidizer was utilized (A.Casha, personal communication, September 2, 2014).

\subsection{The $2012 \mathrm{CO}^{2} Z W^{\circledR}$ analysis}

The landfill based MW system displayed in Fig. 1 denotes a carbon footprint that is mainly direct. The $\mathrm{CO}^{2} \mathrm{ZW}^{\circledR}$ calculations show a total carbon footprint of 290,793 tonnes of $\mathrm{CO}_{2 \mathrm{eq}}$, out of which 274,349 tonnes of $\mathrm{CO}_{2 \text { eq }}$ are direct emissions, whilst indirect emissions amount to 2,803 tonnes of $\mathrm{CO}_{2 \text { eq. Transport amounts to }}$ 13,641 tonnes, whilst the avoided emissions amount to 14,568 tonnes of $\mathrm{CO}_{2 \mathrm{eq}}$.

Comparing indicators makes it possible to appreciate their value. The figures obtained for Malta were compared to those of Catalonia, Spain since both are affected by the seasonality of the tourism industry and have similar waste generation figures, with the Catalan region producing $1.35 \mathrm{~kg} /$ capita/per day in 2012 . Table 1 clearly notes that figures for Malta are much higher than those of Catalonia, however this disparity is set to decrease with the introduction of new facilities (see Table 2 and Table 3 ).

In Fig. 2 and Table 3 the analysis of the carbon footprint per
Table 1

Comparison of $\mathrm{CO}_{2 \text { eq }}$ emission figures from Malta and Catalonia, Spain.

\begin{tabular}{lll}
\hline & Malta & Catalonia, Spain \\
\hline $\begin{array}{l}\mathrm{CO}_{2 \text { eq }} / \text { tonne of municipal waste/year } \\
\mathrm{kg} \text { of } \mathrm{CO}_{2 \text { eq }}\end{array}$ & 1,169 & 401 \\
$\begin{array}{l}\mathrm{CO}_{2 \text { eq }} \text { per inhabitant/year } \\
\mathrm{kg} \text { of } \mathrm{CO}_{2 \text { eq }}\end{array}$ & 690 & 191 \\
\hline
\end{tabular}

waste flow is provided. Landfilling is the main source of direct emissions with 268,463tonnes of $\mathrm{CO}_{2 \mathrm{eq}}$, whilst indirect impact amounts of 1,664 tonnes of $\mathrm{CO}_{2 \mathrm{eq}}$ and avoided impact amounted to 1,694 tonnes of $\mathrm{CO}_{2 \text { eq. }}$. On the other hand, the mixed waste treated through the MBT causes a direct impacts of 5,481 tonnes of $\mathrm{CO}_{2 \mathrm{eq}}$ and an indirect impact of 1,049 tonnes of $\mathrm{CO}_{2 \mathrm{eq}}$, whilst total recycling of source separated collection avoids a total of $-7,778$ tonnes of $\mathrm{CO}_{2 \text { eq. }}$. As noted earlier, transport contributes with 13,641 tonnes of $\mathrm{CO}_{2 \text { eq }}$ or $4.9 \%$ of total emissions.

Whilst some might argue that transportation amounts to $4.9 \%$ of total emissions, it constitutes an inseparable part of an integrated MW management system which is present at every stage from collection to final disposal (Braschel et al., 2013). These results correspond to those of the EU-27 whereby the collection and transport of waste accounts for less than $5 \%$ of estimated GHG 
Table 2

Results of carbon footprint analysis under the different scenarios.

\begin{tabular}{|c|c|c|c|}
\hline & Total carbon footprint tonnes of $\mathrm{CO}_{2 \mathrm{eq}}$ & $\mathrm{Kg} \mathrm{CO}_{2 \mathrm{eq}} /$ inhabitant-yr & $\mathrm{Kg} \mathrm{CO}_{2 \mathrm{eq}} /$ ton-yr \\
\hline 2012 & 290,793 & 690 & 1169 \\
\hline 2018 Option A scenario - Introduction of a 120,000 ton energy to waste facility & 95,468 & 218 & $\underline{362}$ \\
\hline 2018 Option B scenario - Export of waste & $\underline{105,753}$ & 241 & $\overline{401}$ \\
\hline 2018 Option C scenario - Landfilling of waste & $\overline{125,580}$ & 287 & $\overline{476}$ \\
\hline
\end{tabular}

Table 3

GHG emission analysis of the 2012 and the three 2018 scenarios as per CO2ZW ${ }^{\circledR}$ and savings for the three scenarios presented.

\begin{tabular}{|c|c|c|c|c|c|}
\hline & $\begin{array}{l}\text { Source separated waste }(\mathrm{t} \\
\left.\mathrm{CO}_{2 \mathrm{eq}}\right)\end{array}$ & $\begin{array}{l}\text { Mixed general waste to } \mathrm{MBT}(\mathrm{t} \\
\left.\mathrm{CO}_{2 \text { eq }}\right)\end{array}$ & $\begin{array}{l}\text { Incineration }(\mathrm{t} \\
\left.\mathrm{CO}_{2 \mathrm{eq}}\right)\end{array}$ & $\begin{array}{l}\text { Landfill (t } \\
\left.\mathrm{CO}_{2 \mathrm{eq}}\right)\end{array}$ & $\begin{array}{l}\text { Transportation }(\mathrm{t} \\
\left.\mathrm{CO}_{2 \mathrm{eq}}\right)\end{array}$ \\
\hline 2012 & $-7,778$ & 1,902 & 28 & 268,432 & 13,641 \\
\hline $\begin{array}{l}\text { Option A - Introducing a 120,000 tonne } \\
\text { incinerator }\end{array}$ & $-11,218$ & $-7,599$ & 37,677 & 17,728 & 13,905 \\
\hline $\begin{array}{l}\text { Option B - Export of mixed waste for } \\
\text { incineration }\end{array}$ & $-11,035$ & $-10,392$ & 40,345 & 23,516 & 14,088 \\
\hline Option C - Introducing an additional landfill & $-12,559$ & $-10,414$ & 777 & 97,947 & 13,905 \\
\hline
\end{tabular}

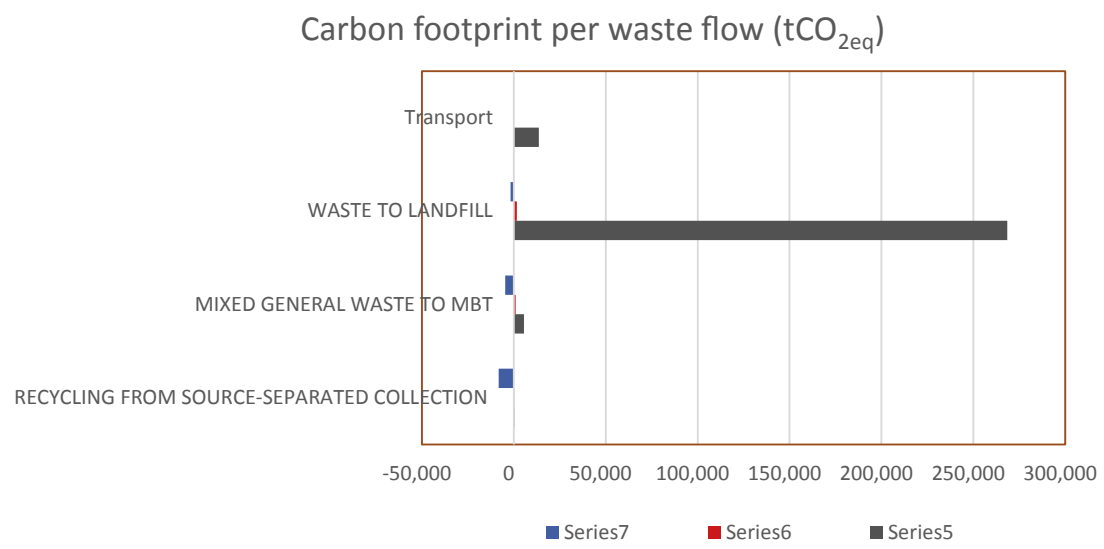

Fig. 2. Flows of waste in Malta with their respective carbon footprint in $\mathrm{tCO}_{2 \mathrm{eq}}$.

emissions (Skovgaard et al., 2008). The economic and environmental problems associated with waste transportation include energy and fuel consumption, and significant amounts of emitted pollutants (Zsigraiová et al., 2009). The research presented here is the first attempt to include waste transport related emissions as part of the carbon footprint in Malta.

The importance of route optimisation shouldn't however be underestimated. Optimisation, together with developing routes which are better suited for every locality's needs, has, in some cases, led to a saving of between 10 and 15 min of collection time (McLeod and Cherrett, 2008) and an 11.3\% reduction in distance travelled by each garbage truck (Nguyen-Trong et al., 2017). Collection and transportation of solid waste often accounts for a substantial percentage of the total waste management budget (including labour costs) (Tavares et al., 2009).

Vehicles emit significant levels of undesirable atmospheric pollutant emissions which include carbon dioxide $\left(\mathrm{CO}_{2}\right)$ and nitrogen oxide $\left(\mathrm{NO}_{\mathrm{x}}\right)$ that contribute to GHGs and acid rain respectively. In conclusion, optimisation yields both environmental and financial benefits (Tavers et al., 2009) and deserves attention also in view that public institutions are increasingly expected to apply the principles of economy, efficiency and effectiveness (GarziaSanchez, 2008), also to communal waste removal services which are expected to meet essential environmental and social demand for GHG reduction and the need for sustainable resource management (Gosten et al., 2011). The Waste Management Plan 2014-2018 notes that "a study to determine the ideal size/s of Refuse Collection Vehicles to reflect dimensions of Maltese roads and their respective standards" will be commissioned and that municipalities will be required to integrate green public procurement in their criteria (MSDEC, 2014).

\subsection{Material flow analysis of the proposed 2018 system(s)}

The Waste Management Plan, 2014-2020 sees the introduction of a number of facilities to assist with the treatment of waste. An overview of these facilities is provided below:

(1) A Mechanical Biological Treatment Plant (MBT-AD) (known as Malta North) started operations in 2016. The plant is coupled with an Anaerobic Digester (AD) which is able to process either MW or at source separated biowaste in a series of mechanical and biological treatment steps (WasteServ, 2013). The plant (denoted in pink in Fig. 3) handles 76,000 tons/year of MW with 15\% allowed for extra capacity (S. Dimech, personal communication, October 15, 2015). It is designed to recover recyclables (e.g. metals), produce RDF, recover energy from the Combined Heat and Power (CHP) plant fueled by biogas and produce a refined digestate. A biogas CHP plant is included to maximise energy recovery. Electricity shall be exported to the grid whilst waste heat from the exhaust systems will be used within the process 


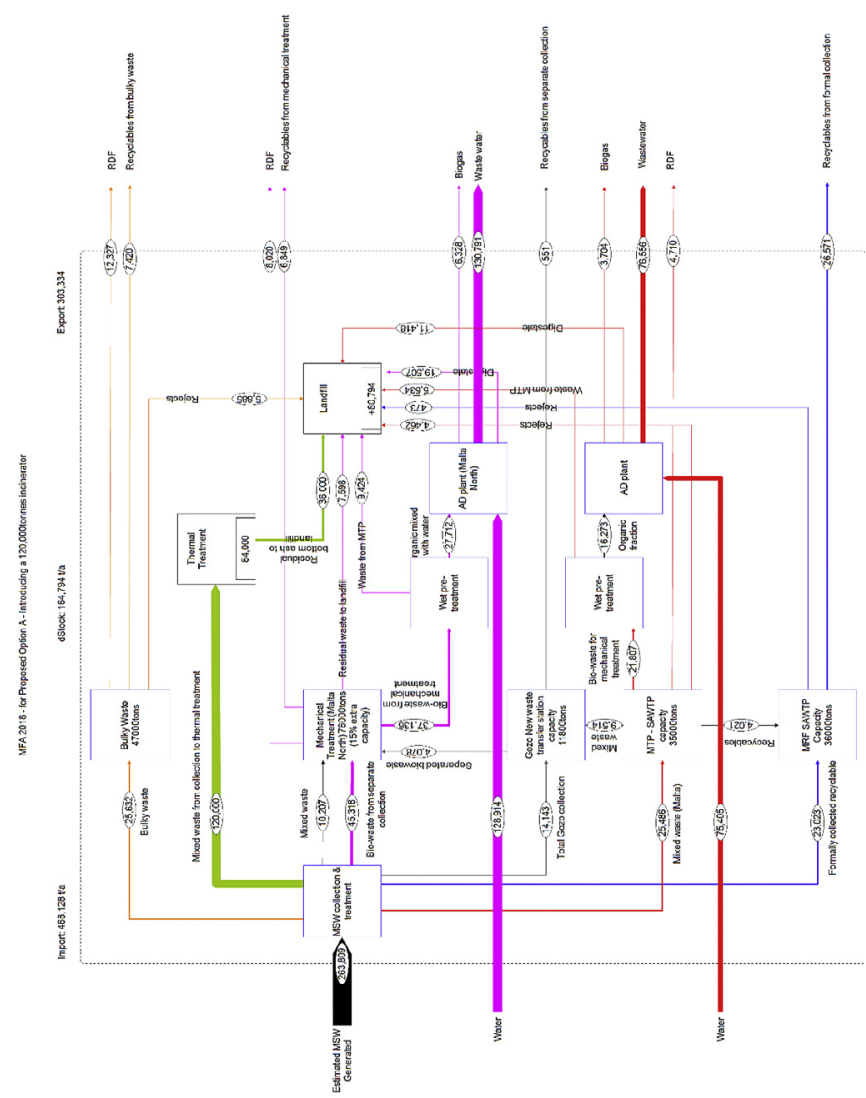

Fig. 3. A flow analysis of the first proposed system in the Waste Management Plan 2014-2020 presenting Option A - introducing a waste-to-energy plant (in tonnes). Data Source: WasteServ Malta Ltd and Waste Management Unit forming part of the MEPA.

(WasteServ, 2013). The waste is processed to have the organic fraction and RDF extracted from the remaining waste which shall be directed from the landfill (MSDEC, 2014). The plant will also be able to handle 47,000 tons/year of bulky waste (denoted in orange in Fig. 1), 35,000 tons/year manure and 4,000 tons/year poultry dung (C. Toscano, personal communication. June 12, 2015).

(2) A waste transfer station in Gozo for the receipt, sorting, processing, interim storage and transfer of wastes originating from Gozo and Comino with a capacity of 11,800 tons (MSDEC, 2014). The MRF has 3 main functions and will allow for closed environment processing - (1) pre-treatment of dry recyclables, (2) the hermetic sealing of MW and, where possible, (3) the shredding of bulky waste. All materials are then transferred to Malta for further treatment (ACR+, n.d.).

Further to the development of the above technologies, additional treatment options would be required to deal with the fractions generated from the facilities themselves (RDF, rejects from MBT and MRF plants), together with the remaining non-recyclable/ non-recoverable waste which exceeds the available capacity.

The Waste Management Plan 2014-2020 points out that these waste streams will be managed in any one or a combination of the following options:

(a) the introduction of a waste-to-energy 120,000 tons facility;

(b) increasing export of recyclable materials, refuse derived fuel (RDF) and the material recovered from the MBT mainly for energy recovery and option; (c) the landfilling of all material.

The projected MFA is shown in Fig. 3. Similar to Fig. 1, it presents a directed graph which runs from left to right with all figures in tonnes. The Waste Management Plan 2014-2020 projects that in 2018 MW generation will reach 263,809 tonnes (MSDEC, 2013), whilst population will reach 438,166 (Eurostat, 2015, 2016).

The additional treatment facilities and the introduction of separate biowaste collection denote a more complex treatment system than that presented for 2012. Fig. 3 denotes Option A which focuses on the introduction of a 120,000 tonne Energy from Waste (EfW) facility (green line) and a new MBT (Malta North) plant (pink line).

The heavy green line signifies that the EfW facility will handle the majority of mixed waste. A separate collection for biowaste was launched in 2015 in five localities and is being extended. The system requires the organic waste fraction to be collected three times a week from households, whilst recyclables are collected through the existing grey bag system and kerbside (bring-in sites) collection (MSDEC, 2014). Based on the Catalonian experience which was introduce in 2008 and focused on door-to-door collection and bring-in system, a 30\% success rate is assumed in the separate biowaste collection (Regions for Recycling, 2014).

Fig. 3 displays how the different fractions will be treated. Taking a top-down approach, the first fraction represents (orange line) bulky waste. Based on 2012 figures, it is estimated that 25,632 tonnes will be generated. Following treatment, these will be divided into 12,327 tonnes RDF, 7,420 tonnes of recycables and 5,885 tonnes of rejects which are landfilled.

The heavy green line shows the thermal treatment facility which is expected to handle 120,000 tonnes. Incineration eliminates the organic part and therefore the final products of the combustion are no longer reactive making the waste chemically and physically stable (Pelloni, L., 2014). Assuming a weight reduction of 70\% (MSDEC, 2014), 36,000 tonnes of bottom ash will be landfilled.

The MBT facility (Malta North) (pink line), it is assumed that it will handle a total of 59,603 tonnes, out of which 10,207 tonnes are mixed whilst 49,396 tonnes $(45,318+4,078$ tonnes) are separated biowaste. Fig. 3 points out that residual waste to landfill amounts to 7,598 tonnes and 9,424 tonnes (waste from MTP) will be landfilled whilst 8,020 tonnes and 6,849 tonnes are processed into RDF and recyclables respectively. Figures for water are based on the IPCC permit application (WasteServ Malta Ltd, 2013).

The Gozo waste transfer facility (grey line), will handle an estimated 14,143 tonnes out of which 551 tonnes are recyclables. At a $30 \%$ success rate 4,078 tonnes consist of separately collected biowaste which is processed at the Malta North Facility whilst 9,514 tonnes are mixed waste and treated at SAWTP.

SAWTP (red line), would be handling 35,000 tonnes, which will generate 4,710 tonnes of RDF, whilst 4,462 tonnes are rejects and therefore landfilled.

The MRF will handle 27,044 tonnes. In this case, 473 tonnes would be rejected and sent to landfill whilst 26,571 tonnes are exported.

The 2018 MFA shows that although no direct landfilling will take place, following the different treatment processes, 80,794 tonnes will need to be disposed of. Furthermore, Fig. 3 assumes that RDF is exported. However, if it is landfilled space for an additional 25,057 tonnes are required. Fig. 3 also points out that more effort is required in order to increase the assumed $30 \%$ success rate since the denoted system needs to handle large quantities of mixed waste, whilst operating under capacity in the case of separated recyclables and bulky waste. This also requires that the Malta North facility handles 10,207 tonnes of mixed waste with the clean 
biowaste fraction, leading to a less than desirable digestate.

An MFA representing Option B i.e. the export of mixed waste, would see the line denoted in green redirected outside the system boundary for export purposes. Selecting Option B would mean that the 120,000 tonnes of mixed waste which, under Option A (Fig. 3) would be incinerated, would be exported, most likely for incineration (in view that the waste is mixed). This means that 329 tonnes of mixed waste would need to be exported every day making it burdensome both administratively and financially.

Selecting Option C, that is, introducing an additional landfill, would see the line denoted in green redirected towards the landfill. This means that an additional 120,000 tonnes of mixed waste would need to be disposed of every year, causing total landfilled waste to reach 170,258 tonnes. In an island where space is very limited, a new landfill siting would be subject to extensive scrutiny and widespread NIMBY feelings burdening this option already from its inception. It should be noted that the current landfill facility is expected to last till 2020 with the present landfilling rate of $0.27 \mathrm{~m}^{3} /$ year (MSDEC, 2013).

The three options also mean a different carbon footprint. The results are presented here:

Introducing an incinerator generates a carbon footprint of 95,468 tonnes of $\mathrm{CO}_{2 \text { eq }}$ with a direct impact of 76,521 tonnes, whilst the indirect one amounts to 5,042 tonnes. Avoided emissions amount to 44,975 tonnes. Transportation generates 13,905 tonnes.

Option B denotes an increase in the carbon footprint, amounting to 105,753 tonnes of $\mathrm{CO}_{2 \text { eq }}$ resulting from the increase in transport. Direct emissions amount to 86,638 tonnes, whilst indirect ones amount to 5,028 tonnes. Avoided emissions reach 49,230 tonnes. In this case transport contributes to 14,088 tonnes of $\mathrm{CO}_{2 \mathrm{eq}}$, whilst in the two other options it amounts to 13,905tonnes. It should be pointed that since exports are mainly done by ship, the $\mathrm{CO}_{2} \mathrm{ZW}^{\circledR}$ tool was amended with freight transport emissions calculated at $0.116 \mathrm{~kg} / \mathrm{km}$ of $\mathrm{CO}_{2 \text { eq }}$ (Ecoinvent 2.2, 2010). Since the $\mathrm{CO}_{2} \mathrm{ZW}^{\mathbb{B}}$ analysis takes a lifecycle approach the calculation also includes the emissions from the incineration of mixed waste that is exported to other countries.

Under Option $\mathrm{B}, \mathrm{CO}_{2 \text { eq }}$ per inhabitant amounts to $241 \mathrm{~kg}$ whilst $362 \mathrm{~kg}$ of $\mathrm{CO}_{2 \mathrm{eq}}$ per tonne of waste are generated. Landfilling would generate 23,516 tonnes of $\mathrm{CO}_{2 \mathrm{eq}}$, whilst incineration generates 40,345 tonnes of $\mathrm{CO}_{2 \text { eq. }}$. Recycling, on the other hand, saves 11,035 tonnes of $\mathrm{CO}_{2 \text { eq }}$, whilst waste processed in MBT plants saves 10,392 tonnes of $\mathrm{CO}_{2 \mathrm{eq}}$.

If an additional landfill is built, the total carbon foot print would reach 125,580 tonnes of $\mathrm{CO}_{2 \mathrm{eq}}$, with direct impact amounting to 106,215 tonnes, and indirect reaches 5,460 tonnes. Avoided impact amounts to 35,924 tonnes, whilst transport generates 13,905 tonnes.

In Option $\mathrm{C}$, the total $\mathrm{CO}_{2 \mathrm{eq}}$ emissions amount to 125,580 tonnes out of which 106,215 tonnes are direct whilst 5,460 tonnes are indirect. In this case avoided impact amounts to 35,924 tonnes of $\mathrm{CO}_{2 \mathrm{eq}}$. Choosing this option means that a total of $287 \mathrm{~kg}$ of $\mathrm{CO}_{2 \mathrm{eq}}$ per inhabitant or $476 \mathrm{~kg}$ of $\mathrm{CO}_{2 \mathrm{eq}}$ per tonne of waste generated. This option would also entail locating a site for a new landfill, a task which will definitely not prove to be easy.

\section{Conclusions}

MW is not homogenous in nature and therefore requires a number of systems to handle and treat it. This can be noted in the two MFAs presented, which, despite their complexity, provide a detailed picture of every process starting from collection to disposal/export.

The scenarios presented for 2018 clearly point out that source separation of both dry recyclables and biowaste needs to be augmented. With the current figures, both the bulky waste facility and the MRF are running under capacity. In addition to this, the assumed 30\% biowaste separation rate, would still require that mixed waste is processed with the clean fraction leading to less than desirable digestate output.

The carbon footprint analysis brings out the importance of taking GHG emissions into consideration when designing waste policies. The close relationship between waste and GHG emissions can be noted since most waste management technologies and processes are sources of GHGs. These can be reduced by minimizing landfill gas emissions and transport or by re-configuring the system through, for example, the avoidance of landfilling, redesigning of collection routes etc. This will lead to savings which are usually gained outside the waste management system, leading to an environmental benefit at the societal level (Gentil et al., 2009)

Sorting MW prior to collection has been a preferred approach (Chen and Lo, 2016) in various countries. Both the separation of recyclables in the MRF and of biowaste are of great benefit to GHG emissions. This is clearly backed up in the carbon footprint studies for the 3 options presented, whereby the recycling of dry material saves an average of 11,604 tonnes of carbon equivalents whilst the treatment of separated biowaste saves an average of 9,468 tonnes of $\mathrm{CO}_{2 \text { eq. }}$.

It can therefore be concluded that the new MBT facility will benefit the Maltese Islands. The new site is located in the disused Maghtab landfill and therefore since it is already in a derelict state, it will have minimal impact on the surrounding environment. Even when assuming a 30\% biowaste separation success rate, it reduces carbon emissions for all three options presented.

The 2018 options analysis clearly points out that the introduction of a 120,000 ton incinerator will have the lowest carbon footprint. However, in the case of a small island state like Malta, the decision cannot exclude the land footprint requirements. The analysis of the three options presented notes that landfilling waste will cause the highest carbon footprint also causing extensive demands on land requirements.

Transport accounts for an average of 13,966 tonnes of $\mathrm{CO}_{2 \mathrm{eq}}$. A definite improvement would be to work on route optimisation of daily waste collection. Presently municipalities, in their procurement process, specify that trucks must have Euro 3 or 4 specifications (A. Agius, personal communication, March 27, 2015), however routes are left entirely in the hands of collectors, leaving room for extensive improvement.

All in all the management of waste in Malta remains a constant challenge. The size and population density of the Maltese Islands play an important role in waste related decisions. However, this research has proven that the utilization of MFA tools and carbon footprint analysis can effectively guide waste management policies towards improved efficiency.

\section{Funding}

This research was funded by the Malta Government Scholarship Scheme, under the Ministry of Education and Employment, Malta. The funding did not have a direct role in the research conducted.

\section{Acknowledgments}

A special thank you is extended to Ing. MaryGrace Micallef who provided advice with regards to the functioning of the MBT facilities and Mr Darren Cordina within the Waste Management Unit within MEPA, who provided immediate response to all my information requests. Thank you also to $\mathrm{Mr}$ Oliver Cencic for his help with the use of STAN software. 


\section{References}

Ackerman, F., 2000. Waste management and climate change. Local Environ. Int. J. Justice Sustain. 5 (2), 223-229. http://dx.doi.org/10.1080/13549830050009373. Retrieved from. http://dx.doi.org/10.1080/13549830050009373.

$\mathrm{ACR}+$ (n.d). Wasteserv - new transfer station and materials recovery facility opened in gozo. Retrieved from. http://www.acrplus.org/index.php/fr/2013-06-11-1023-55/actualites-de-nos-membres/575-wasteserv-new-transfer-station-andmaterials-recovery-facility-opened-in-gozo

Agamuthu, P., Herat, S., 2014. Sustainable waste management in small islands developing states (SIDS). Waste Manag. Res. 32 (8), 681-682. http://dx.doi.org/ $10.1177 / 0734242 \times 14544869$.

Ballinger, A., Hogg, D., 2015. The Potential Contribution of Waste Management to a Low Carbon Economy. Eunomia Research and Consulting Ltd. commissioned by Zero Waste Europe. Retrieved from. http://www.zerowasteeurope.eu/ downloads/the-potential-contribution-of-waste-management-to-a-lowcarbon-economy/ (Accessed 14 Dec. 2015).

Bogner, J., Abdelrafie Ahmed, M., Diaz, C., Faaij, A., Gao, Q., Hashimoto, S. Mareckova, K., Pipatti, R., Zhang, T., 2007. Waste management, in climate change. In: Metz, B., Davidson, O.R., Bosch, P.R., Dave, R., Meyer, L.A. (Eds.), Mitigation. Contribution of Working Group III to the Fourth Assessment Report of the Intergovernmental Panel on Climate Change. Cambridge University Press, Cambridge, United Kingdom and New York, NY, USA.

Braschel, N., Posch, A., 2013. A review of system boundaries of GHG emission inventories in waste management. J. Clean. Prod. 44, 30-38. http://dx.doi.org/ 10.1016/j.jclepro.2012.10.050.

Brunner, P.H., Rechberger, H., 2005. Practical Handbook of Material Flow Analysis. Taylor \& Francis e-Library, ISBN 0-203-59141-0.

Cencic, O., Rechberger, H., 2008. Material flow analysis with software STAN. Environ. Eng. Manag. J. 18 (1), 3-7. Retrieved from. http://ser.cienve.org.tw/ download/18-1/jeeam18-1_3-7.pdf.

Chen, Y., Lo, S., 2016. Evaluation of greenhouse gas emissions for several municipal solid waste management strategies. J. Clean. Prod. 113, 606-612. http://doi.org. ejournals.um.edu.mt/10.1016/j.jclepro.2015.11.058.

Cifrian, E., Galan, B., Andres, A., Viguri, J.R., 2012. Material flow indicators and carbon footprint for MSW management systems: analysis and application at regional level, Cantabria, Spain. Resour. Conservation Recycl. 68, 54-66.

Council Directive 1999/31/EC of 26 April 1999 on the landfill of waste 1999 OJ L 182/ 1.

Council Directive 2008/98/EC on waste (Waste Framework Directive) 2008 OJ L312.

Deschenes, P.J., Chertow, M., 2004. An island approach to industrial ecology. Towards sustainability in the Island Context. J. Environ. Plan. Manag. 47 (2), 201-217. http://dx.doi.org/10.1080/0964056042000209102. March 2004.

Eckelman, M.J., Ashton, W., Arakaki, Y., Hanaki, K., Nagashima, S., Malone-Lee, L., 2014. Island waste management systems. Statistics, challenges, and opportunities for applied industrial ecology. J. Industrial Ecol. 18 (2), 306-316.

Ecoinvent 2.2, 2010. Ecoinvent Centre. Retrieved from. http://www.ecoinvent.org/ database/older-versions/ecoinvent-version-2/ecoinvent-version-2.html.

European Commission, 2014. Communication from the Commission to the European Parliament, the Council, the European Economic and Social Committee and the Committee of Regions. Towards a circular economy: A zero waste programme for Europe. COM, 398 final/2.

European Environment Agency, 2011. Big Potential of Cutting Greenhouse Gases from Waste. Retrieved from. http://www.eea.europa.eu/highlights/bigpotential-of-cutting-greenhouse.

European Environment Agency, 2012. Movements of Waste across the EU's Internal and External Borders. EEA Report No. 7/2012. Office for Official Publications of the European Union, Luxembourg. http://dx.doi.org/10.2800/62637.

Eurostat, 2015a. Each Person in the EU Generated $481 \mathrm{Kg}$ of Municipal Waste in 2013. 43\% Was Recycled or Composted (News Release 54/2015). Retrieved from. http://ec.europa.eu/eurostat/documents/2995521/6757479/8-26032015-AP-EN. pdf/a2982b86-9d56-401c-8443-ec5b08e543cc.

Eurostat, 2016. Population Projections. Retrieved from http://ec.europa.eu/eurostat/ $\operatorname{tgm} /$ table.do? tab $=$ table\&init $=1 \&$ language $=$ en \&pcode $=$ tps00002\&plugin $=1$.

Eurostat, 2011. Generation and Treatment of Municipal Waste. (Eurostat Statistics in Focus 31/2012). Retrieved from. http://ec.europa.eu/eurostat/web/productsdatasets/-/tsdpc240 (Accessed on 10 September 2015)

Eurostat, 2012. Municipal Waste 'Reference Metadata in Euro SDMX Metadata Structure (ESMS)'. Retrieved from. http://ec.europa.eu/eurostat/cache/ metadata/en/env_wasmun_esms.htm (Accessed on 5 November 2013).

Falzon, C., Fabri, S.G., Frysinger, S., 2013. Integrated waste management as a climate change stabilisation wedge for the Maltese Islands. Waste Manag. Res. 31 (1), 73-79. http://dx.doi.org/10.1177/0734242x12468198.

Farreny, R., Colman, S., Gasol, C.M., et al., 2012. CO2ZW Carbon Footprint Tool for Waste Management in Europe. User Guide. Retrieved from. http://co2zw.eu. sostenipra.cat.

Fishedick, M., Roy, J., Abdel-Aziz, A., et al., 2014. Industry. In: Climate Change 2014: Mitigation of Climate Change. Contribution of Working Group III to the Fifth Assessment Report of the Intergovernmental Panel on Climate Change. Cambridge University Press, Cambridge, United Kingdom and New York, NY, USA

Galdes, R., 2007. Waste Management and Sustainable Tourism in Small Islands (Unpublished Masters' thesis). University of Malta, Malta.

García-Sánchez, I.M., 2008. The performance of Spanish solid waste collection. Waste Manag. Res. 26 (4), 327-336. http://dx.doi.org/10.1177/
0734242 X07081486.

Gentil, E., Christensen, T.H., Aoustin, E., 2009. Greenhouse gas accounting and waste management. Waste Manag. Res. 27 (8), 696-706. http://dx.doi.org/10.1177 0734242 X09346702.

Gosten, A., Rucker, T., Winkelmann, W., 2011. The Berlin Biogas-Project - the production of biomethane from organic waste. In: Thome-Kozmiensky, K.L. L.Pelloni (Eds.), Waste Management - Recycling, Composting, Fermentation, Mechanical-biological Treatment, Energy Recovery from Waste, Sewage Sludge Treatment, vol. 2. Mediengruppe Universal Grafische Betriebe, Munich, Germany, pp. 551-563.

Intergovernmental Panel on Climate Change (IPCC), 2006. Guidelines for National Greenhouse Gas Inventories. Retrieved from. http://www.ipcc-nggip.iges.or.jp/ public/2006gl/pdf/5_Volume5/V5_3_Ch3_SWDS.pdf.

International Solid Waste Association (ISWA), 2015, December 9. David Newman Reports from COP21 in Paris. ISWA NEWS. Retrieved from. https://www.iswa. org/index.php?id=1178 (Accessed on 4 April 2016).

Jiang, W., Liu, J., Liu, X., 2016. Impact of carbon quota allocation mechanism on emissions trading: an agent-based simulation. Sustainability 8 (8), 10.3390.

Knauer, K., 2007. Global Warming. The Causes, the Perils, the Solutions, the Actions: 51 Things You Can Do, first ed. Time Books, Time Inc, New York.

Mallia, E., Pulis, A., Spiteri, L., 2013. The Sant' Antnin Waste Treatement Plant in Marsascala. Review of Operations. Retrieved from. http://environment.gov.mt/ en/Documents/Downloads/WBRU/Exec\%20+\%20Full\%20Report.pdf.

Malta Resources Authority (MRA), 2013. National Greenhouse Gas Emissions Inventory for Malta 2013 Annual Report for Submission under the United Nations Framework Convention on Climate Change. Malta Resources Authority, Malta (Annual Report No. Report 4/2013).

Malta Resources Authority (MRA). (n.d.). Mitigation of greenhouse gas emissions. Retrieved from. http://mra.org.mt/climate-change/mitigation-of-greenhousegas-emissions/

McGee, M.J., 2015. 2012: 400PPM CO2 Crossover. Retrieved from. https://www.co2 earth/2012-400-ppm-co2-crossover.

McLeod, F., Cherrett, T., 2008. Quantifying the transport impacts of domestic waste collection strategies. Waste Manag. 28 (2008), 2271-2278. http://dx.doi.org 10.1016/j.wasman.2007.09.041.

Messenger, B. (2015, December 09). ISWA at COP21: Tax Carbon, Recognise the Role of Waste Management in Emission Cuts. Retrieved from http://wastemanagement-world.com/a/iswa-at-cop21-tax-carbon-recognise-the -role-ofwaste-management-in-emission-cut.s

Ministry for Sustainable Development, the Environment and Climate Change (MSDEC), 2013. Issues Paper - towards Sustainable Waste Management. Issued as a Preliminary Consultation Document Prior to the Formulation of Malta's Waste Management Plan 2014 - 2020. http://msdec.gov.mt/en/Documents Downloads/ISSUES PAPER TOWARDS SUSTAINABLE WASTE MANAGEMENT.pdf.

Ministry for Sustainable Development, the Environment and Climate Change (MSDEC), 2014. Waste Management Plan for the Maltese Islands. A Resource Management Approach 2014 - 2020. Retrieved from. https://msdec.gov.mt/en/ Document\%20Repository/Waste\%20Management\%20Plan\%202014\%20-\% 202020\%20-\%20Final\%20Document.pdf.

National Statistics Office, Malta, 2011. Demographic Review, 2010. Pg. vi Retrieved from. http://www.nso.gov.mt/statdoc/document_file.aspx?id=317.

National Statistics Office, Malta, 2012. Census of Population and Housing 2011. Preliminary report. Retrieved from, p. 3. http://www.nso.gov.mt/statdoc/ document_file.aspx?id=3424.

Nguyen-Trong, K., Nguyen-Thi-Ngoc, A., Nguyen-Ngoc, D., Dinh-Thi-Hai, V., 2017 Optimization of municipal solid waste transportation by integrating GIS analysis, equation-based, and agent-based model. Waste Manag. 59, 14-22. http:/| dx.doi.org/10.1016/j.wasman.2016.10.048.

Organisation for Economic Co-operation and Development (OECD), 2013. Waste Management Services. DAF/COMP(2013)26. Retrieved from. http://www.oecd. org/daf/competition/Waste-management-services-2013.pdf.

Pelloni, A., 2014. Incineration - an indispensable element of a responsible waste management. In: Thome-Kozmiensky, K.L., S.Thiel (Eds.), Waste Management Waste-to-energy, vol. 4. Mediengruppe Universal Grafische Betriebe, Munich, Germany, pp. 41-47.

Regions for Recycling, 2014. Good Practices Catalonia: Biological Treatment and Separate Collection of Biowaste. Retrieved from. http://www.regions4recycling eu/upload/public/Good-Practices/GP_ARC Biowaste-collection.pdf.

Saladié, Ò., 2016. Determinants of waste generation per capita in catalonia (northeastern Spain): the role of seasonal population. Eur. J. Sustain. Dev. 5 (3), 489-504. http://dx.doi.org/10.14207/ejsd.2016.v5n3p489.

Salhofer, S., Schneider, F., Obersteiner, G., 2007. The ecological relevance of transport in waste disposal systems in Western Europe. Waste Manag. 27, S47-S57. http://dx.doi.org/10.1016/j.wasman.2007.02.025.

Sevigne, I., Gasol, C.M., Farreny, R., Rieradevall, J., Gabarrell, X., 2013. CO2ZW: carbon footprint tool for municipal solid waste management for policy options in Europe. Inventory of Mediterranean countries. Energy Policy. 56, 623-632. http://dx.doi.org/10.1016./j.enpol.2013.01.027.

Shelnick, S. (n.d.) Near-Infrared with Algorithms Likely Top Separation Technology For Plastics Recycling. Retrieved from https://separation.wikispaces.com/ Plastics+Technology. (Accessed on 24 March 2015).

Skovgaard, M., Hedal, N., Villaneuva, A., 2008. Municipal Waste Management and Greenhouse Gases (ETC/RWM Working paper 2008/1). Retrieved from. http:/ scp.eionet.europa.eu/publications/wp2008_1/wp/wp1_2008.

Tartaglia, S., 2015. A Smart Tool to Improve Citizens' Awareness on Sustainable 
Waste Management Practices in the Maltese Islands. Unpublished masters' thesis. University of Malta, Malta.

Tavares, G., Zsigraiova, Z., Semiao, V., Carvalho, M.G., 2009. Optimisation of MSW collection routes for minimum fuel consumption using 3D GIS modelling. Waste Manag. 29 (3), 1176-1185. http://doi.org.ejournals.um.edu.mt/10.1016/j. wasman.2008.07.013.

United Nations, 2016. List of Parties that Signed the Paris Agreement on 22 April. Retrieved from. http://www.un.org/sustainabledevelopment/blog/2016/04/ parisagreementsingatures/.

United Nations Commission on Sustainable Development (UNCSD), 1999. Progress in the Implementation of the Programme of Action for the Sustainable Development of Small Island Developing Countries. Retrieved from. http://islands. unep.ch/d99-6a2.htm (Accessed on 5 April 2016).

United Nations Environmental Programme (UNEP), 2010. Waste and Climate Change. Global Trends and Strategy Framework. Osaka/Shiga: Division of Technology, Industry and Economics International, Environmental Technology Centre.
Vienna University of Technology (TUV), 2012. Stan2Web. Retrieved from. http:// www.stan2web.net.

WasteServ Malta Ltd, 2013. Integrated Pollution and Prevention Control Consolidated Application. Malta North Waste Treatment Plant (IP007/13). Operation of a Mechanical Treatment Plant with Anaerobic Digester \& a Biogas Plant for Animal Manure Supporting Information. Retrieved from. https://www.mepa. org.mt/file.aspx?f=12472.

WasteServ Malta Ltd. (n.d). Maghtab Environmental Complex. Rehabilitation of Closed Dumbsites. Retrieved from www.wastesermalta.com/Maghtab (Accessed 25 January 2016).

Zeng, S., Chen, J., 2016. Forecasting the allocation ratio of carbon emission allowance currency for 2020 and 2030 in China. Sustainability 8 (7), 650. http:// dx.doi.org/10.3390/su8070650.

Zsigraiová, Z., Tavares, G., Semiao, V., Carvalho, M. d. G., 2009. Integrated waste-toenergy conversion and waste transportation within island communities. Energy 34 (5), 623-635. http://dx.doi.org/10.1016/j.energy.2008.10.015. 